University of Nebraska - Lincoln

DigitalCommons@University of Nebraska - Lincoln

USDA National Wildlife Research Center - Staff Publications
U.S. Department of Agriculture: Animal and Plant Health Inspection Service

June 2005

\title{
SENSORY MODALITY USED BY COYOTES IN RESPONDING TO ANTIPREDATOR COMPOUNDS IN THE BLOOD OF TEXAS HORNED LIZARDS
}

\author{
Wade C. Sherbrooke \\ Southwestern Research Station, American Museum of Natural History \\ J. Russell Mason \\ USDA-APHIS-Wildlife Services, National Wildlife Research Center
}

Follow this and additional works at: https://digitalcommons.unl.edu/icwdm_usdanwrc

Part of the Environmental Sciences Commons

Sherbrooke, Wade C. and Mason, J. Russell, "SENSORY MODALITY USED BY COYOTES IN RESPONDING TO ANTIPREDATOR COMPOUNDS IN THE BLOOD OF TEXAS HORNED LIZARDS" (2005). USDA National Wildlife Research Center - Staff Publications. 511.

https://digitalcommons.unl.edu/icwdm_usdanwrc/511

This Article is brought to you for free and open access by the U.S. Department of Agriculture: Animal and Plant Health Inspection Service at DigitalCommons@University of Nebraska - Lincoln. It has been accepted for inclusion in USDA National Wildlife Research Center - Staff Publications by an authorized administrator of DigitalCommons@University of Nebraska - Lincoln. 


\title{
SENSORY MODALITY USED BY COYOTES IN RESPONDING TO ANTIPREDATOR COMPOUNDS IN THE BLOOD OF TEXAS HORNED LIZARDS
}

\author{
WADE C. Sherbrooke* AND J. Russell Mason \\ Southwestern Research Station, American Museum of Natural History, P.O. Box 16553, Portal, AZ 85632 (WCS) \\ USDA-APHIS-Wildlife Services, National Wildlife Research Center, 4101 LaPorte Avenue, \\ Fort Collins, CO 80521-2154 (JRM) \\ *Correspondent: wos@amnh.org
}

\begin{abstract}
We investigated the hypothesis that the squirting of blood from orbital sinuses by Texas horned lizards (Phrynosoma cornutum) is an antipredator defense against some mammalian species. Coyotes (Canis latrans) were tested for the first time. As expected, Texas horned lizards squirted blood in response to coyote attacks, and coyotes exhibited startle response, avoidance response, or both as a result of these events. Whereas lizard carcasses mixed into normal foodmash elicited regurgitation by coyotes, possibly due to physical effects, blood of horned lizards similarly mixed into food did not. Coyote responses to simulated squirts of 5 compounds, including blood of horned lizards, into 3 potential sensory target areas (eyes, nose, and mouth) strongly suggested that aversive effects were mediated by receptors in the oral or nasal cavities. Coyote responses were more frequent to delivery of blood plasma and whole blood of Phrynosoma to buccal and nasal membranes than to delivery of plasma and blood from spiny lizards (Sceloporus jarrovii) or to delivery of a saline control to these membranes. We concluded that Texas horned lizards squirt blood from sinuses surrounding the eyes during attacks by canids, such as coyotes, and that this blood affects oral receptors, causing a negative response in coyote attack behavior that potentially increases survival of the lizards.
\end{abstract}

\begin{abstract}
RESUMEN-Investigamos la hipótesis de que el lanzamiento de un chorro de sangre por los senos orbitales por los camaleones texanos (Phrynosoma cornutum), es una defensa antidepredatoria contra algunas especies mamíferas. Coyotes (Canis latrans) fueron probados por primera vez. Como era de esperarse, los camaleones arrojaron sangre en respuesta a los ataques de los coyotes, y los coyotes se mostraron sorprendidos, las evitaron, o hicieron ambos como resultado de los eventos. Mientras que los cadáveres de las lagartijas mezcladas con alimento típico provocaron vómito en los coyotes, posiblemente debido a efectos físicos, la sangre de camaleones mezclada con la comida no lo produjo. Las respuestas de los coyotes a lanzamientos simulados de 5 compuestos, incluyendo sangre de camaleones, hacia 3 áreas potencialmente sensitivas del coyote (ojos, nariz y boca), sugieren fuertemente que los efectos de rechazo fueron provocados por receptores en cavidades orales o nasales. Respuestas de coyotes fueron más frecuentes con lanzamiento de plasma sanguíneo y sangre entera de Phrynosoma a las membranas nasales y orales que con lanzamiento de plasma y sangre provenientes de lagartijas espinosas (Sceloporus jarrovii), o con lanzamiento de un control salino en esas membranas. Concluimos que los camaleones arrojan chorros de sangre por los senos que rodean sus ojos durante ataques de caninos, como coyotes, y que esta sangre afecta los receptores orales, causando una respuesta negativa en el comportamiento del ataque del coyote que probablemente incrementa la supervivencia de las lagartijas.
\end{abstract}

The ability of horned lizards in the genus Phrynosoma to squirt blood from ocular sinus tissues surrounding the eye has been known for over a century (Wallace, 1871; Middendorf and Sherbrooke, 1992; Manaster, 1997; Sherbrooke and Middendorf, 2001). Nevertheless, a demonstration that the biological role, among numerous competing hypotheses, is most likely a defense against canid predators has been elucidated only recently in a series of trials with domesticated dogs (Middendorf and Sherbrooke, 1992; Sherbrooke and Middendorf, 2001) and kit foxes (Vulpes macrotis) (Sherbrooke and Middendorf, 2004). Two ma- 
jor issues in determining that this behavior is an antipredator defense in Texas horned lizards seem to have been established: 1) it is employed by horned lizards when under attack by a taxonomically-limited category of predators (certain canids) and not during attacks by other potentially lethal non-canid predators (Sherbrooke, 1990a, 1991; Middendorf and Sherbrooke, 1992; Sherbrooke and Middendorf, 2001, 2004; Sherbrooke, 2003), and 2) the squirted blood deters attacks by kit foxes, a native canid (Sherbrooke and Middendorf, 2004).

Studies have begun on the identification of chemical components of the blood that might effect this defense (Middendorf et al., 2001; Sherbrooke and Kimball, unpubl. data), and the blood has been noted to have the ability to detoxify the venom of harvester ants (Pogonomyrmex) eaten by Texas horned lizards (Schmidt et al., 1989). Apparently, not all species of horned lizards squirt blood in response to predators (Sherbrooke and Middendorf, 2001; Hodges, 2004; Sherbrooke et al., 2004; Sherbrooke and Mendoza-Quijano, 2005). The blood-squirting mechanism, based on bloodflow control in the head (Bruner, 1907; Heath, 1966), and its evolution have been discussed (Sherbrooke, 2000; Sherbrooke and Middendorf, 2004). The targeted mammalian-sensory receptors of the chemical constituents of squirted blood have not been studied previously.

Coyotes (Canis latrans) represent a potentially significant source of canid predation on horned lizards because their ranges are largely coincident in North America (Hall and Kelson, 1959; Sherbrooke, 2003). This study addresses 2 issues: do coyotes display a negative feeding response to blood squirted by horned lizards that could inhibit or terminate predatory attacks? If so, which sensory system is targeted by horned lizards to effect a negative response?

\footnotetext{
Methods-Adult Texas horned lizards (Phrynosoma cornutum; $n=49$ ) were collected from Hidalgo County, New Mexico, and Cochise County, Arizona, during May and June 1999 (Sherbrooke, 2002) and maintained at the Southwestern Research Station in outdoor enclosures, near Portal, Arizona. They were fed seed-harvester ants (Pogonomyrmex) or commercially raised crickets (Acheta domesticus) and watered for rain-harvesting (Sherbrooke, 1990b, 1995). Adult Yarrow's spiny lizards (Sceloporus jarrovii) $(n=29)$
}

were collected along North Fork of Cave Creek and East Turkey Creek, Chiricahua Mountains, Cochise County, Arizona, 22 through 25 June 1999, maintained in outdoor enclosures, fed crickets, and watered. Lizards were transported to Utah for tests with randomly selected coyotes at the Predation Ecology and Behavioral Applications Field Station (Millville) of the National Wildlife Research Center (USDAAPHIS-Wildlife Services), Utah State University, Logan.

Blood samples were collected from $S$. jarrovii on 28 June and from $P$. cornutum on 30 June by puncturing the post-orbital sinus with a $75-\mathrm{mm}, 75-\mu \mathrm{L}$ capacity, heparinized microhematocrit capillary tube. Following centrifugation in 3-cc vials, blood plasma was pipetted off and refrigerated. Fresh whole blood also was collected from the post-orbital sinus of individual spiny lizards and horned lizards immediately $(1 \mathrm{~min})$ prior to coyote trials involving the 3 sensory target areas.

Captive-raised adult coyotes were housed in individual chain-link-fence kennels $(3.6 \times 1.2 \times 1.8 \mathrm{~m})$ with cement flooring and PVC den boxes. Testing occurred in these home kennels. Throughout testing, coyotes were permitted ad libitum access to water and meat-based chow (Furbreeders Cooperative, Logan, Utah) daily at $0730 \mathrm{~h}$. Maintenance procedures have been described elsewhere (Knowlton et al., 2001).

Two live Phrynosoma were used in initial testing with 2 coyotes on 28 June (1600 h MDT). Subsequently, on 29 June, 2 additional live Phrynosoma and 8 individual coyotes were used for preliminary observations of predator-prey interactions for periods $\geq 5$ min.

Feeding trials with 2 post-attack (29 June) carcasses of $P$. cornutum, laterally divided in half, and whole carcasses of recently-sacrificed juvenile $S$. jarrovii were conducted by mixing lizard parts in meat-based chow and offering the 20-g mixtures in empty feeding bowls to 8 coyotes on 29 June (late afternoon). All samples of lizards were of approximately the same weight. We monitored coyotes for feeding responses.

On 30 June $(1600 \mathrm{~h}), 15$ coyotes were tested in 3 groups for responses to 20 -g preparations of meatbased chow mixed with the contents of 2 capillary tubes $(150 \mu \mathrm{L})$ of 1 of 3 substances: blood plasma of Sceloporus, blood plasma of Phrynosoma, or a saline solution (control). A fourth group, 5 coyotes, received a food bolus containing $0.4 \mathrm{~g}$ of residual redblood cells of Phrynosoma.

Five test compounds were used in trials simulating blood-squirting to determine sensory responses of coyotes: 1$)$ saline solution $(0.9 \%$ sodium chloride; Aqualife System, Abbott Laboratories), 2) blood plasma of Sceloporus, 3) freshly collected (from postorbital sinuses) whole blood of Sceloporus, 4) blood 
plasma of Phrynosoma, and 5) freshly collected (from post-orbital sinuses) whole blood of Phrynosoma. Each test compound was held in a microhematocrit tube $(75 \mu \mathrm{L})$ and attached to an infusion set (\# 4492 Butterfly, 21-gage $\times 0.75$-inch needle, 12-inch tubing; Abbott Hospitals Inc., North Chicago, Illinois) at the end of a 3-mL plastic syringe pre-charged with $1 \mathrm{cc}$ of air for explosive propulsion of the test compound from the tip of the microhematocrit.

The amount of material applied, $75 \mu \mathrm{L}$, approximates the amount of blood first squirted by a lizard when molested by a canid. The quantity was estimated from dog-initiated trials, where blood was collected following numerous squirting events (manually induced and counted) and the mass of an average squirt was determined to be $0.025 \mathrm{~g}$ (Sherbrooke and Middendorf, 2001). Assuming the density of horned lizard blood to be close to that of water $(1 \mathrm{~g}=1 \mathrm{cc}=1 \mathrm{~mL})$, then the amount of squirted blood would be $0.025 \mathrm{~mL}$. Our simulated squirt samples were 3 times larger $(0.075 \mathrm{~mL})$ because we assumed that the first squirt, or first few squirts in a series (which might number as many as 54 in a 1.5-min trial; Sherbrooke and Middendorf, 2001), would be somewhat larger than average.

The 5 test compounds were applied (from $<2 \mathrm{~cm}$ ) to 3 target areas (rear of tongue; single nasal opening; or a single open eye) of the 38 coyotes ( $17 \mathrm{fe}$ male, 21 male) in an opportunistic sequence depending on the position of the restrained animal. A treatment consisted of applying 1 compound to 1 of the 3 sensory areas. Three areas were used with 3 coyotes before a repeat compound treatment was applied. On 1, 2, and 5 July, 5 trials of each compound (5) to each sensory area (3) were performed (75 total trials), both morning and afternoon. A few individual coyotes received 2 treatments in $1 \mathrm{~d}$, but never of the same compound or to the same target area. Trials were video-recorded and evaluated subsequently. Responses of coyotes during the first 3 min following applications were scored by 3 evaluators (2 with extensive coyote behavioral experience, and 1 with experience with dog and kit fox responses to blood of horned lizards; and all 3 with experience from watching preliminary, staged encounters of coyotes and Phrynosoma). A score of 1 was given in any trial in which the coyote exhibited behaviors such as lateral head-shaking, jaw gaping, or tongue licking, and 0 to any trials in which these buccal behaviors were lacking. In comparing treatment results, probability values were generated with binomial tests (Siegel, 1956), with a $P<0.01$ level of significance accepted. Other potential behaviors, such as eye-blinking, tearing, or nasal snorting, were monitored.

REsults-In the 2 initial observations with live horned lizards, one lizard squirted blood at the coyote. The coyote responded with gaping and licking of its oral cavity, and subsequently did not kill the lizard. In the second trial, the lizard apparently squirted blood just before it was killed by the coyote, after repeatedly being picked up by the body (not head), and dropped. Once the head of this lizard was crunched by the carnassials, it was cut up and eaten (handling time $=3 \mathrm{~min}$ ), following which the coyote regurgitated $(<1 \mathrm{~min})$ a food bolus containing the remains of the lizard. Then the coyote went through 3 series of reingestion-regurgitation episodes with the same bolus. By the last reingestion, some horn, dorsal skin, and hindleg or tail segments of the well-chewed lizard remains were not reingested, apparently selectively, with the bolus.

In these 2 initial trials, both coyotes exhibited exaggerated mouth movements in response to the blood squirting by the horned lizard. Both lizards raised tails while under attack. In the subsequent 8 coyote-horned lizard interactions with 2 lizards, 3 coyotes elicited blood squirting by one horned lizard to which the coyotes reacted by opening and closing their mouths and shaking their heads laterally. One lizard raised its tail twice while under attack. Although both lizards died as a result of injuries, mainly to limbs and tail, neither lizard carcass was fully consumed.

Of the 8 coyotes receiving food mixed with parts of dead lizards, the 4 that ate carcasses of Sceloporus did not exhibit distress or drink water after feeding. In contrast, of the 4 coyotes eating a bolus with half of a carcass of Phrynosoma, 3 exhibited gastric distress; 2 regurgitated food and 1 wrenched its fore-body as in a pre-regurgitation action. All 4 coyotes drank water following eating.

In feeding trials with 20 coyotes ( 4 treatments: blood plasma of Sceloporus, blood plasma of Phrynosoma, red-blood cells of Phrynoso$m a$, and saline solution), 19 food boluses were eaten within 10 minutes without any coyote exhibiting adverse feeding behaviors or regurgitation. One coyote failed to eat a saline control bolus within the first half hour but had consumed it several hours later. No evidence was found of regurgitation of any bolus at that time or the following morning.

For each of the 5 compounds used in simulated-squirting trials, responses by coyotes (Table 1) included opening and closing the 
TABLE 1-Number of simulated blood-squirting trials in which an oral behavioral response by a coyote (Canis latrans) was recored. Five test fluids were squirted into 3 sensory-system areas; ocular, nasal, and buccal. Each of the 5 treatments was repeated 5 times. All responses scored for coyotes involved their buccal cavity and tonque (even for one ocular treatment). There were 2 different reponses from eye tissues (see text) and none involving reponses from nasal tissues.

\begin{tabular}{|c|c|c|c|c|c|c|}
\hline \multirow[b]{2}{*}{ Treatment area } & \multirow{2}{*}{$\begin{array}{l}\text { Control } \\
\text { (saline) }\end{array}$} & \multicolumn{2}{|c|}{ Sceloporus } & \multicolumn{2}{|c|}{ Phrynosoma } & \multirow{2}{*}{$\begin{array}{c}\text { Total for } \\
\text { sensory area }\end{array}$} \\
\hline & & Blood plasma & Whole blood & Blood plasma & Whole blood & \\
\hline Ocular & 0 & 0 & 0 & 1 & 0 & 1 \\
\hline Nasal & 0 & 1 & 0 & 2 & 5 & 8 \\
\hline Buccal & 1 & 0 & 1 & 3 & 5 & 10 \\
\hline $\begin{array}{c}\text { Total for fluid } \\
\text { treatment }\end{array}$ & 1 & 1 & 1 & 6 & 10 & - \\
\hline
\end{tabular}

mouth (in a flapping fashion), excessive tongue licking of the mouth, and lateral headshaking (Sherbrooke and Middendorf, 2004). A single tearing response to whole blood of Phrynosoma and one case of eye-blinking to blood plasma of Phrynosoma were noted, but not scored (Table 1). No nasal responses, such as forced-air cleansing or muscular twitching of external nares, were noted in any simulatedsquirting trials; responses to nasal applications (Table 1) were all buccally mediated gaping and lateral head-shaking. No compound consistently elicited responses in all 3 sensory target areas. Saline control trials $(n=15)$ to the 3 areas elicited one response. Similarly, applications of the blood plasma or whole blood of Sceloporus $(n=30)$ to 3 areas elicited one response for each compound.

In contrast to trials with blood of Sceloporus, 30 applications of blood plasma or whole blood of Phrynosoma elicited 16 responses. Coyotes responded in all trials when whole blood of Phrynosoma was applied to buccal and nasal targets $(n=10)$. The single buccal response to ocular applications of all compounds $(n=$ 25) was to blood plasma of Phrynosoma. There were 8 responses to nasal applications $(n=$ 25); 7 involved blood of Phrynosoma $(n=10)$. Similarly, there were 10 responses to buccal applications $(n=25) ; 8$ were to blood of Phrynosoma $(n=10)$.

In comparing responses of coyotes to whole blood of Phrynosoma to other fluid treatments to the 3 target areas, probabilities were as follows: control $(P=0.006)$, blood plasma of $\mathrm{Sce}^{-}$ loporus $(P=0.006)$, whole blood of Sceloporus $(P=0.006)$, blood plasma of Phrynosoma $(P=$ $0.227)$, and in comparing blood plasma of
Phrynosoma to other treatments, respectively: $(P$ $=0.062),(P=0.062)$, and $(P=0.062)$. Thus, reactions of coyotes to whole blood of Phrynosoma significantly differed $(P<0.01)$ from all other treatments, except blood plasma of Phrynosoma. Differences in responses to blood plasma of Phrynosoma versus the 3 non-Phrynosomablood treatments approached statistical significance $(P=0.062)$.

Discussion-The probability of Texas horned lizards squirting blood from the orbital sinuses clearly is related to the presence of a potential predator such as a dog (70 to $100 \%$ in trials, Middendorf and Sherbrooke, 1992; Sherbrooke and Middendorf, 2001), kit fox (75\% in trials; Sherbrooke and Middendorf, 2004), or, more rarely, a human $(5.9 \%$, Lambert and Ferguson, 1985). Our initial observations of 4 Texas horned lizards in staged encounters with 10 coyotes confirmed that coyotes elicited blood-squirting responses by these lizards when threatened, in $50 \%$ of these trials, and that the coyotes reacted to the squirted blood in all cases. This result was similar to those of studies with other canids (Middendorf and Sherbrooke, 1992; Sherbrooke and Middendorf, 2001, 2004). The report by Collins (1984, 1985) of a coyote eating 2 Texas horned lizards that did not squirt blood (observed from a distance of $1 \mathrm{~m}$; personal letter to WCS from J. T. Collins, 1986) does not negate the hypothesis that blood-squirting might serve as an antipredator defense with coyotes. The defensive success of blood squirting need not be absolute, but might be influenced by the level of hunger of the predator (Sherbrooke and Middendorf, 2004), nor need it be employed 
under all conditions (human presence could inhibit its use) for it to have evolved. The effect on predator response of concentrated squirted blood on buccal receptors might be distinct from blood ingested during consumption of a lizard.

The regurgitation of a food bolus immediately after swallowing pieces of chewed horned lizard and subsequent reingestion and repeated regurgitation was unusual (JRM, pers. observ.), although coyotes frequently regurgitate food on demand to pups (Snow, 1967). The gastric distress exhibited by 3 coyotes, in separate trials following ingestion of normal food mixed with partial carcasses of horned lizards, confirmed this digestive-tract response. No regurgitation response was seen in trials with kit foxes, despite their killing and eating of Texas horned lizards (Sherbrooke and Middendorf, 2004; WCS, pers. obser.). Interestingly, foods laced with samples of blood of horned lizards or blood of Sceloporus did not elicit a regurgitation response. This observation suggests that the swallowing of horned-lizard body parts might have induced regurgitation responses physically rather than chemically and might have been a result of captivity, where canids are accustomed to a ground-food diet that lacks hardened, sharp particles of sufficient size to abrade the digestive tract.

The application of 5 substances in trials simulating horned-lizard blood squirting to 3 sensory areas of the heads of coyotes revealed that responses differed depending on the targeted sensory system. The number of responses to blood of Phrynosoma (whole blood and blood plasma) exceeded the number of responses to blood of Sceloporus (whole blood and blood plasma) and to saline, suggesting that the coyotes were responding to compounds present in blood plasma of Phrynosoma. Fifteen of these responses to blood of Phrynosoma were to treatments to the nasal or buccal areas, and only one response was to ocular application. We concluded that the eyes are not particularly sensitive to chemicals in horned-lizard blood, at least not at the concentrations or amounts used. Putative defensive compounds in the blood do not seem to be irritants, although eyes of coyotes have large numbers of irritant receptors (Green et al., 1990). Earlier literature suggested that eyes might be targets of blood squirting (Middendorf and Sherbrooke,
1992) and that blood of Phrynosoma might contain irritating compounds (Middendorf et al., 2001); however, our data do not support these views.

Nasal and buccal applications elicited similar numbers of responses ( 8 and 10 , respectively), with whole blood of Phrynosoma (10) being more effective than plasma (5). The frequency of these target area responses to whole blood and plasma of Phrynosoma (15 of 20 trials; $75 \%$ ) was higher than that to whole blood and plasma of Sceloporus (2 of 20 trials; 10\%). We concluded that blood of Phrynosoma contained compounds different from blood of Sceloporus, and these different chemical constituents of blood were responsible for the adverse oral-behavioral responses to blood of horned lizards. Some differences in the blood chemistry between these 2 species of lizards are related to differing abilities to detoxify the venom of ants (Pogonomyrmex), the prey of horned lizards (Schmidt et al., 1989). These ants might be a source of defensive compounds in the blood of Phrynosoma (Sherbrooke and Middendorf, 2004).

Our casual observations of responses to both oral and nasal applications suggested a potentially greater lag time in response to nasal applications. This potential difference suggests that chemicals from the blood could have been transported from the nasal passages, via the internal nares, to the rear of the buccal cavity, where they elicited responses. Clarification of responses to chemical compounds in blood of Phrynosoma in these 2 sensory areas will require additional study. We suspect that the target receptors of blood-borne chemicals are in the oral cavity and could be either taste or trigeminal chemoreceptors (Green et al., 1990).

An oral location of chemical target receptors might be expected from our observed interactions and timing of blood squirting in encounters between live lizards and coyotes. Typically, lizards squirt blood (following predator approach and initial molestation) immediately after the jaws of a canid close over the head of a lizard (Sherbrooke, 2003: plates 98 and 99 of kit foxes). Eyelid swelling, due to ocular sinus engorgement with blood (Sherbrooke, 2003: plate 96) was observed to reach a pre-squirting stage (Middendorf and Sherbrooke, 1992) in one coyote trial prior to tactile contact by the predator. The sequence of events, including 
the lizard raising its tail during attacks, resembled observations made in trials of Texas horned lizards with a dog and with kit foxes (Middendorf and Sherbrooke, 1992; Sherbrooke and Middendorf, 2004). The defensive blood-squirting response of Texas horned lizards is highly specific in its application, both as to selection of the predator (canids) against which it is employed, and as to the specific buccal area targeted. Responses of coyotes to application of blood of $P$. cornutum to buccal receptor areas in these trials supports the hypothesis that these lizards squirt blood from ocular sinuses to enhance survival by deterring predation.

Study protocol was approved by the Institutional Animal Care and Use Committee of the National Wildlife Research Center, Predation Ecology and Behavioral Applications Field Station. For assistance in obtaining blood samples and with coyote trials we thank D. Zemlicka, and with coyote trials, P. Cross. We thank G. A. Middendorf, III, and reviewers for constructively editing the manuscript and P. Garcia for translating the abstract into Spanish. Permits to collect lizards were supplied by the Arizona Department of Game and Fish and the New Mexico Game and Fish Department.

\section{Literature Cited}

BRUNER, H. L. 1907. On the cephalic veins and sinuses of reptiles, with description of a mechanism for raising the venous blood-pressure in the head. American Journal of Anatomy 7:1-117.

Collins, J. T. 1984. The lizards of Oz. Kansas Wildlife $41: 12-16$.

Collins, J. T. 1985. Natural Kansas. University Press of Kansas, Lawrence.

Green, B. G., J. R. Mason, And M. R. Kare. 1990. Chemical senses, volume II: irritation. Marcel Dekker, New York.

Hall, E. R., AND K. R. Kelson. 1959. The mammals of North America. Ronald Press Co., New York.

HeAth, J. E. 1966. Venous shunts in the cephalic sinuses of horned lizards. Physiological Zoology 39:30-35.

Hodges, W. L. 2004. Defensive blood squirting in Phrynosoma ditmarsi and a high rate of humaninduced blood squirting in Phrynosoma asio. Southwestern Naturalist 49:67-70.

Knowlton, F. F., M. Roetto, And D. Briggs. 2001. Serological responses of coyotes to two commercial rabies vaccines. Journal of Wildlife Disease 37:798-802.

Lambert, S., and G. M. Ferguson. 1985. Blood ejec- tion frequency by Phrynosoma cornutum (Iguanidae). Southwestern Naturalist 30:616-617.

MANASTER, J. 1997. Horned lizards. University of Texas Press, Austin.

Middendorf, G. A., III, ANd W. C. Sherbrooke. 1992. Canid elicitation of blood-squirting in a horned lizard (Phrynosoma cornutum). Copeia 1992:519527.

Middendorf, G. A., III, W. C. Sherbrooke, And E. J. BRAUN. 2001. Comparison of blood squirted from the circumorbital sinus and systemic blood in a horned lizard, Phrynosoma cornutum. Southwestern Naturalist 46:384-387.

Schmidt, P. J., W. C. Sherbrooke, and J. O. Schmidt. 1989. The detoxification of ant (Pogonomyrmex) venom by a blood factor in horned lizards (Phrynosoma). Copeia 1989:603-607.

SHerbrooke, W. C. $1990 a$. Predatory behavior of captive greater roadrunners feeding on horned lizards. Wilson Bulletin 102:171-174.

SHERBRoOKE, W. C. $1990 b$. Rain-harvesting in the lizard, Phrynosoma cornutum: behavior and integumental morphology. Journal of Herpetology 24: 302-308.

SHerbrooke, W. C. 1991. Behavioral (predator-prey) interactions of captive grasshopper mice (Onychomys torridus) and horned lizards (Phrynosoma cornutum and P. modestum). American Midland Naturalist 126:187-195.

Sherbrooke, W. C. 1995. Collecting and feeding harvester ants (Pogonomyrmex spp.) to captive horned lizards (Phrynosoma spp.). Herpetological Review 26:25-26.

SHERbrooke, W. C. 2000. Sceloporus jarrovii (Yarrow's spiny lizard): ocular sinus bleeding. Herpetological Review 3:243.

SHerbrooke, W. C. 2002. Seasonally skewed sex-ratios of road-collected Texas horned lizards (Phrynosoma cornutum). Herpetological Review 33:2124.

SHerbrooke, W. C. 2003. Introduction to horned lizards of North America. University of California Press, Berkeley.

Sherbrooke, W. C., E. Beltran-Sanchez, F. MendoZa-Quijano, B. Baur, and G. A. Middendorf, III. 2004. Is there an antipredator blood-squirting defense in the bull horned lizard, Phrynosoma taurus? Herpetological Review 35:345-347.

Sherbrooke, W. C., AND F. Mendoza-Quijano. 2005. Phrynosoma braconnieri (short-tail horned lizard). Defensive behavior. Herpetological Review 36: $65-66$.

Sherbrooke, W. C., AND G. A. Middendorf, III. 2001. Blood-squirting variability in horned lizards (Phrynosoma). Copeia 2001:1114-1122.

Sherbrooke, W. C., And G. A. Middendorf, III. 2004. Responses of kit foxes (Vulpes macrotis) to antipredator blood-squirting and blood of Texas 
horned lizards (Phrynosoma cornutum). Copeia 2004:652-658.

SIEGEL, S. 1956. Nonparametric statistics for the behavioral sciences. McGraw-Hill Book Company, New York.

SNow, C. J. 1967. Some observations on the behavioral and morphological development of coyote pups. American Zoologist 7:353-355.
WALLACE, A. R. 1871. Extract from letters addressed to A. R. Wallace, from John Wallace, Stockton, California (May, 1870), regarding blood ejection from eyes of Phrynosoma. Proceedings of the Zoological Society of London 1871:1-2.

Submitted 9 September 2003. Accepted 19 September 2004. Associate Editor was Cheri A. Jones. 